\title{
The Roots of the Poet
}

\section{María Jesús Monzón ${ }^{1}$}

${ }^{1}$ ESNE (Escuela Universitaria de Diseño, Madrid, Spain)

E-mail: mariajesus.mon.ro@gmail.com

Website: https://mariajesusmonzonr.weebly.com/

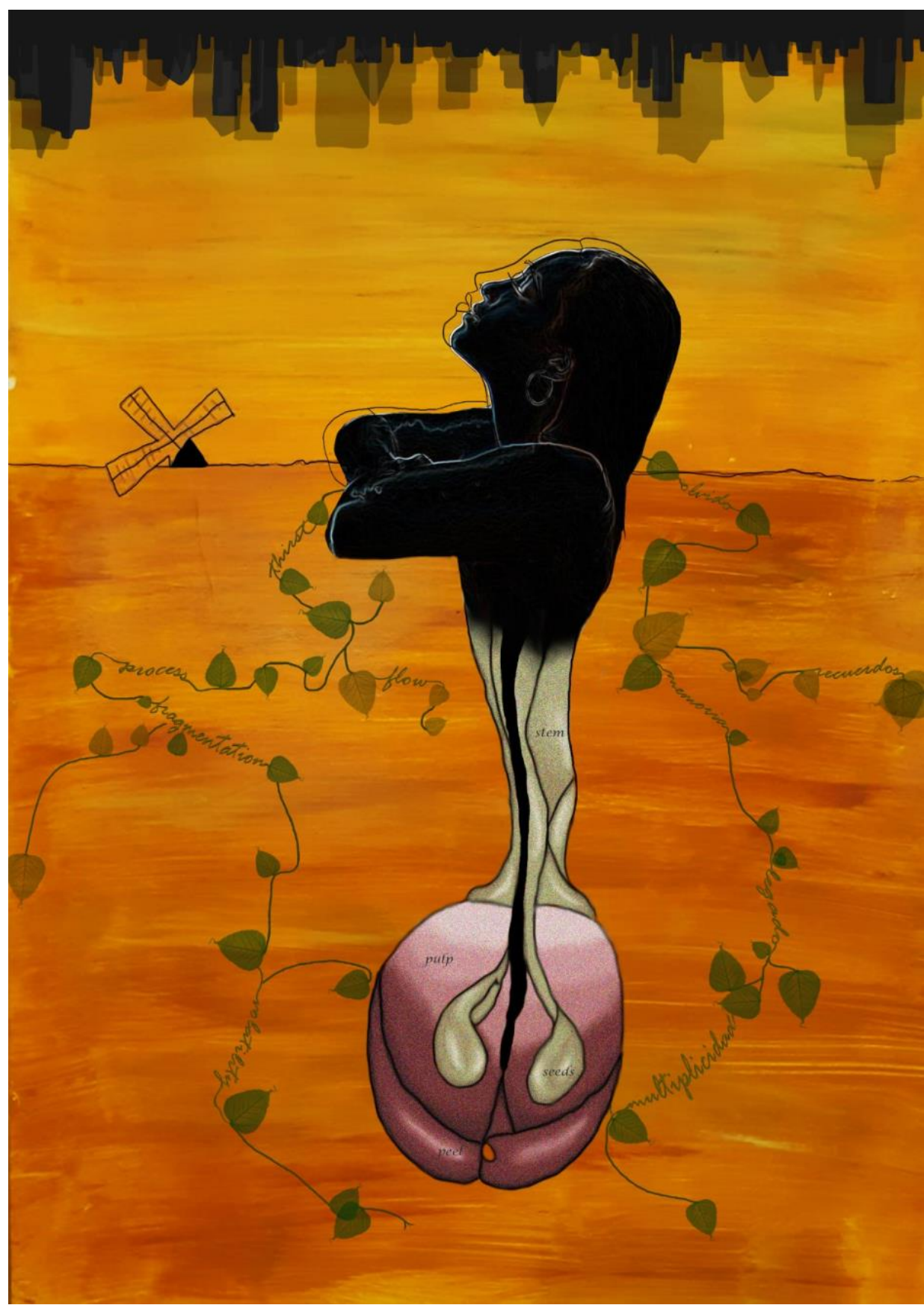

